\title{
Assessment of the cardiovascular safety of saxagliptin in patients with type 2 diabetes mellitus: pooled analysis of 20 clinical trials
}

\author{
Nayyar lqbal ${ }^{1 *}$, Artist Parker ${ }^{2}$, Robert Frederich ${ }^{1}$, Mark Donovan $^{1}$ and Boaz Hirshberg ${ }^{2}$
}

\begin{abstract}
Background: It is important to establish the cardiovascular (CV) safety profile of novel antidiabetic drugs.

Methods: Pooled analyses were performed of 20 randomized controlled studies $(N=9156)$ of saxagliptin as monotherapy or add-on therapy in patients with type 2 diabetes mellitus (T2DM) as well as a subset of 11 saxagliptin + metformin studies. Adjudicated major adverse CV events (MACE; CV death, myocardial infarction [MI], and stroke) and investigator-reported heart failure were assessed, and incidence rates (IRs; events/100 patient-years) and IR ratios (IRRs; saxagliptin/control) were calculated (Mantel-Haenszel method).

Results: In pooled datasets, the IR point estimates for MACE and individual components of CV death, MI, and stroke favored saxagliptin, but the $95 \% \mathrm{Cl}$ included 1. IRR (95\% Cl) for MACE in the 20-study pool was $0.74(0.45$, 1.25). The Cox proportional hazard ratio $(95 \% \mathrm{Cl})$ was $0.75(0.46,1.21)$, suggesting no increased risk of MACE in the 20-study pool. In the 11-study saxagliptin + metformin pool, the IRR for MACE was $0.93(0.44,1.99)$. In the 20-study pool, the IRR for heart failure was $0.55(0.27,1.12)$.
\end{abstract}

Conclusions: Analysis of pooled data from 20 clinical trials in patients with T2DM suggests that saxagliptin is not associated with an increased CV risk.

Keywords: Dipeptidyl peptidase-4 inhibitor, Major adverse cardiovascular events, Saxagliptin, Type 2 diabetes mellitus

\section{Introduction}

Cardiovascular (CV) disease is the leading cause of mortality and morbidity in patients with type 2 diabetes mellitus (T2DM) [1]. In the United States, the prevalence of self-reported CV disease in people with T2DM is estimated to be $>30 \%$ [2], and CV events account for almost $70 \%$ of diabetes-related deaths in individuals aged $\geq 65$ years $[1]$.

Although epidemiologic studies suggest that hyperglycemia is associated with adverse CV events [3-5], the effects of intensive glycemic control on CV outcomes in interventional studies are not clear [6-8]. Moreover, in some studies and with some antihyperglycemic drugs, a tendency toward an increased risk for $\mathrm{CV}$ events has

\footnotetext{
* Correspondence: nayyar.iqbal@bms.com

'Bristol-Myers Squibb, Route 206 \& Providence Line Rd, Princeton, NJ 08543, USA

Full list of author information is available at the end of the article
}

been reported $[7,9,10]$. However, follow-up of prominent clinical trials in type 1 [11] and T2DM [12] suggest that intensive glycemic control may reduce $\mathrm{CV}$ events over the long term.

Because of the uncertainty surrounding glycemic control and $\mathrm{CV}$ events and the association of increased CV events with some antihyperglycemic drugs, in 2008 the US Food and Drug Administration recommended that CV safety be assessed as a component of the clinical development program of new antihyperglycemic drugs [13].

Saxagliptin is a dipeptidyl peptidase-4 (DPP-4) inhibitor approved as an adjunct to diet and exercise to improve glycemic control in adults with T2DM [14]. DPP-4 inhibitors are oral antihyperglycemic agents that inhibit the inactivation of the incretin hormones, glucagon-like peptide-1 (GLP-1) and glucose-dependent insulinotropic peptide, resulting in increased glucose-dependent insulin secretion and suppression of glucagon secretion 
[15]. Observational evidence suggests that GLP-1 may have protective effects on the CV system, independent of glucose control [16]. However, DPP-4 is increased in patients with T2DM $[17,18]$ and elevated circulating DPP-4 is associated with subclinical left ventricular dysfunction in these patients [18]. Therefore, it is of interest to assess the CV safety of DPP-4 inhibitors.

In randomized, controlled, clinical trials, saxagliptin was effective and well tolerated over 24 weeks in improving glycemic control when used as monotherapy $[19,20]$ and as add-on therapy to metformin [21], glyburide [22], or a thiazolidinedione [23] in patients with T2DM. The advantages of DPP-4 inhibitors are their tolerability, a low rate of hypoglycemia, and weight neutrality [24].

Results from large outcome trials of saxagliptin in patients with prior $\mathrm{CV}$ disease or multiple $\mathrm{CV}$ risk factors (SAVOR) [25] and alogliptin in patients after acute coronary syndrome (EXAMINE) have recently been published [26] and have shown that saxagliptin and alogliptin do not increase or decrease major adverse CV events (MACE). In contrast to those trials in patients with T2DM and high $\mathrm{CV}$ risk, the current analysis evaluated MACE and its individual component events of $\mathrm{CV}$ death, myocardial infarction (MI) and stroke, as well as heart failure, with saxagliptin in the general population of patients with T2DM that participated in the saxagliptin clinical development program. The present analysis expands on a previous assessment of the CV safety of saxagliptin [27] and analyzes MACE in 20 phase 2 and 3 trials of saxagliptin versus placebo or active comparator.

\section{Materials and methods Study design}

This post hoc analysis $(\mathrm{N}=9156)$ used pooled data from 20 randomized phase $2 \mathrm{~b}$ and $3 \mathrm{~b}$ controlled clinical trials of saxagliptin. These trials were placebo-controlled or active-comparator studies of saxagliptin $(2.5,5$, or $10 \mathrm{mg} / \mathrm{d}$ in most studies; 20, 40, or $100 \mathrm{mg} / \mathrm{d}$ in 1 phase $2 \mathrm{~b}$ study) as monotherapy or add-on therapy to metformin, a sulfonylurea, a thiazolidinedione, or insulin \pm metformin for up to 206 weeks (including long-term extension studies) in patients with T2DM (Table 1). Data from the SAVOR study in patients with prior CV disease or multiple CV risk factors were not included in this analysis. In some studies, rescue medication (metformin, pioglitazone, or titrated insulin) was given during the study if patients met prespecified glycemic criteria. In long-term extension studies of monotherapy, patients in the placebo arm received blinded metformin 500 mg. Detailed methodology and primary findings for these studies have been published (Table 1). Patients were followed until completion of the study or premature discontinuation from the study. The studies were performed in accordance with the Declaration of Helsinki and all patients provided written informed consent. The protocols were approved by a local ethics committee.

\section{Analyses}

Adverse events (AEs) and serious AEs (SAEs) were reported by study investigators using standard reporting procedures. AEs were coded using the Medical Dictionary for Regulatory Activities, version 15.0 (MedDRA). AEs occurring up to 1 day following the last treatment day or up to the last visit day in the short-term plus long-term period (where applicable), whichever was later, were included. SAEs occurring up to 30 days following the last treatment day or up to the last visit day in the short-term plus long-term period, whichever was later, were included.

Major adverse CV events, defined as CV death, MI, stroke, and cardiac ischemic events reported by investigators were systematically identified using a list of MedDRA preferred term (PT) diagnoses. All identified potential CV events subsequently went through treatment-blinded adjudication by independent reviewers at the Duke Clinical Research Institute (DCRI; Durham, NC; 8 studies) or the Montreal Heart Institute (MHI; Montreal, QC, Canada; 12 studies).

Briefly, for the studies retrospectively reviewed by DCRI, cases included all deaths, MI, and stroke events as well as all events coded by any of the 148 MedDRA PTs representing possible ischemic events. Methods for full CV event identification have been previously published [27]. For the 12 studies prospectively adjudicated by MHI, the sponsor identified potential cases for adjudication based on AEs and SAEs with PTs that correlated with the following Standardized MedDRA Queries (SMQs) groupings, as defined by the current version of MedDRA: "ischemic heart disease" (adjudicated for possible MI) and "cerebrovascular disorders" (adjudicated for possible stroke). In addition, SAEs (only) with PTs that correlated with the SMQs of "cardiac arrhythmias" or "cardiac failure" were sent for adjudication to determine if the cardiac failure or cardiac arrhythmia was precipitated by MI. Additionally, any event that led to death was identified for adjudication [27]. Heart failure events were not adjudicated and were identified based on PTs from a narrow SMQ for "cardiac failure".

Safety was analyzed in all treated patients, including those meeting rescue medication criteria. Analyses of $\mathrm{CV}$ events were performed using the pooled 20-study dataset and a separate pooled subset of 11 studies of saxagliptin add-on therapy to metformin (NCT00575588, NCT00666458, NCT00661362, NCT00121667, NCT00327015 [included saxagliptin + placebo and saxagliptin + metformin vs metformin + placebo], NCT00757588 [included saxagliptin + insulin \pm metformin or insulin \pm metformin], NCT00683657, NCT00885378, NCT00918138, 
Table 1 Studies included in the 20-study pool

\begin{tabular}{|c|c|c|c|c|c|}
\hline Study & Study design & $\mathrm{N}^{*}$ & $\begin{array}{c}\text { Mean } \\
\text { baseline } \\
\mathrm{HbA}_{1 c} \%\end{array}$ & Treatment & Reference \\
\hline NCT00950599 & $\begin{array}{l}\text { Phase 2, randomized, 6-wk (high-dose cohort) or 12-wk } \\
\text { (main cohort) dose ranging study in treatment-naïve patients }\end{array}$ & 423 & $7.5-8.0$ & $\begin{array}{l}\text { SAXA } 2.5,5,10,20,40 \\
\text { or } 100 \mathrm{mg} / \mathrm{d} \text { vs PBO }\end{array}$ & $\begin{array}{l}\text { Rosenstock et al, } \\
2008[28]\end{array}$ \\
\hline NCT00575588 ${ }^{\dagger}$ & Phase 3, randomized, $52 w k+52-w k$ LTE & 858 & 7.7 & $\begin{array}{l}\text { SAXA } 5 \mathrm{mg} / \mathrm{d}+\text { MET vs } \\
\text { glipizide } 5-20 \mathrm{mg} / \mathrm{d}+\text { MET }\end{array}$ & $\begin{array}{l}\text { Göke et al, 2010; } \\
2013[29,30]\end{array}$ \\
\hline NCT00666458 ${ }^{\dagger}$ & Phase 3 , randomized, $18 \mathrm{wk}$ & 801 & 7.7 & $\begin{array}{l}\text { SAXA } 5 \mathrm{mg} / \mathrm{d}+\text { MET vs } \\
\text { SITA } 100 \mathrm{mg} / \mathrm{d}+\text { MET }\end{array}$ & $\begin{array}{l}\text { Scheen et al, } \\
2010 \text { [31] }\end{array}$ \\
\hline NCT00698932 & $\begin{array}{l}\text { Phase 3, randomized, } 24 \text { wk in treatment-naïve Asian } \\
\text { patients. Rescue medication: metformin }\end{array}$ & 568 & $8.1-8.2$ & SAXA $5 \mathrm{mg} / \mathrm{d}$ vs PBO & Pan et al, 2012 [32] \\
\hline $\mathrm{NCT}^{2} 0661362^{\dagger}$ & Phase 3, randomized, 24 wk in Asian patients & 570 & 7.9 & $\begin{array}{l}\text { SAXA } 5 \mathrm{mg} / \mathrm{d}+\text { MET vs } \\
\text { PBO + MET }\end{array}$ & Yang et al, 2011 [33] \\
\hline NCT00614939 & $\begin{array}{c}\text { Phase 3, randomized, } 12 \text { wk + 40-wk LTE in patients with } \\
\text { renal impairment }\end{array}$ & 170 & $8.1-8.5$ & $\begin{array}{l}\text { SAXA } 2.5 \mathrm{mg} / \mathrm{d} \text { vs PBO } \\
\text { ( } \pm \text { other OADs or INS) }\end{array}$ & $\begin{array}{l}\text { Nowicki et al, } \\
2011[34,35]\end{array}$ \\
\hline NCT00918879 & $\begin{array}{l}\text { Phase 3, randomized, } 24 \text { wk in treatment-naïve Indian } \\
\text { patients. Rescue medication: metformin }\end{array}$ & 213 & 8.3 & SAXA $5 \mathrm{mg} / \mathrm{d}$ vs PBO & $\begin{array}{l}\text { Prasanna Kumar } \\
\text { et al, } 2014 \text { [36] }\end{array}$ \\
\hline NCT00121641 & $\begin{array}{c}\text { Phase 3, randomized, } 24 \text { wk + 42-mo LTE in treatment-naïve } \\
\text { patients. Rescue medication: metformin; placebo arm: } \\
\text { metformin } 500 \text { mg/d during LTE }\end{array}$ & $401^{\ddagger}$ & $7.8-8.0$ & $\begin{array}{c}\text { SAXA } 2.5,5 \text {, or } 10 \mathrm{mg} / \mathrm{d} \text { vs } \\
\text { PBO }\end{array}$ & $\begin{array}{l}\text { Rosenstock et al, } \\
2009 ; 2013[20,37]\end{array}$ \\
\hline NCT00295633 & $\begin{array}{l}\text { Phase 3, randomized, } 24 \text { wk }+52-w k \text { LTE. } \\
\text { Rescue medication: metformin }\end{array}$ & 565 & $8.2-8.4$ & $\begin{array}{c}\text { SAXA } 2.5 \text { or } 5 \mathrm{mg} / \mathrm{d}+\mathrm{TZD} \text { vs } \\
\text { PBO }+ \text { TZD }\end{array}$ & $\begin{array}{l}\text { Hollander et al, 2009; } \\
2011[23,38]\end{array}$ \\
\hline $\mathrm{NCTO}_{0121667^{\dagger}}$ & $\begin{array}{l}\text { Phase 3, randomized, } 24 \text { wk + up to } 42 \text {-mo LTE. } \\
\text { Rescue medication: pioglitazone }\end{array}$ & 743 & 8.0 & $\begin{array}{l}\text { SAXA } 2.5,5 \text {, or } 10 \mathrm{mg} / \mathrm{d}+ \\
\text { MET vs PBO + MET }\end{array}$ & $\begin{array}{l}\text { DeFronzo et al, } \\
\text { 2009; Rosenstock } \\
\text { et al, } 2013[21,37]\end{array}$ \\
\hline NCT00316082 & $\begin{array}{c}\text { Phase 3, randomized, } 24 \text { wk + 52-wk LTE in treatment-naïve } \\
\text { patients. Rescue medication: metformin; placebo arm: } \\
\text { metformin } 500 \text { mg/d during LTE }\end{array}$ & 365 & $7.8-8.0$ & $\begin{array}{l}\text { SAXA } 2.5 \mathrm{mg} \text { QAM } \pm \text { titration } \\
\text { to } 5 \mathrm{mg}, 5 \mathrm{mg} \text { QAM, or } 5 \mathrm{mg} \\
\text { QPM vs PBO }\end{array}$ & $\begin{array}{l}\text { Frederich et al, } \\
2012[19]\end{array}$ \\
\hline NCT00327015 & $\begin{array}{l}\text { Phase 3, randomized, } 24 w k+52-w k \text { LTE in treatment-naïve } \\
\text { patients. Rescue medication: pioglitazone }\end{array}$ & 1306 & $9.4-9.6$ & $\begin{array}{c}\text { SAXA } 5 \text { or } 10 \mathrm{mg} / \mathrm{d}+\text { MET vs } \\
\text { SAXA } 10 \mathrm{mg} / \mathrm{d}+\text { PBO or } \\
\text { MET }+ \text { PBO }\end{array}$ & $\begin{array}{l}\text { Jadzinsky et al, 2009; } \\
\text { Pfützner et al, } \\
2011[39,40]\end{array}$ \\
\hline NCT00313313 & $\begin{array}{l}\text { Phase 3, randomized, } 24 w k+52-w k \text { LTE. } \\
\text { Rescue medication: metformin }\end{array}$ & 768 & $8.4-8.5$ & $\begin{array}{c}\text { SAXA } 2.5 \text { or } 5 \mathrm{mg} / \mathrm{d}+\mathrm{GLY} \text { vs } \\
\text { PBO }+\mathrm{GLY} \text { uptitrated to } \\
15 \mathrm{mg} / \mathrm{d}^{\ddagger}\end{array}$ & $\begin{array}{l}\text { Chacra et al, 2009; } \\
2011[22,41]\end{array}$ \\
\hline NCT00374907 & $\begin{array}{l}\text { Phase 3, randomized, } 12 \mathrm{wk}+104-w k \text { LTE in } \\
\text { treatment-naïve patients. Rescue medication: metformin; } \\
\text { placebo arm: metformin } 500 \mathrm{mg} / \mathrm{d} \text { during LTE }\end{array}$ & 36 & $6.6-6.9$ & SAXA $5 \mathrm{mg} / \mathrm{d}$ vs PBO & $\begin{array}{l}\text { Henry et al, } \\
2011[42]\end{array}$ \\
\hline NCT00757588 ${ }^{\dagger}$ & $\begin{array}{l}\text { Phase 3, randomized, } 24 \text { wk + 28-wk LTE. } \\
\text { Rescue medication: titrated insulin }\end{array}$ & 455 & $8.6-8.7$ & $\begin{array}{c}\text { SAXA } 5 \mathrm{mg} / \mathrm{d}+\mathrm{INS} \pm \mathrm{MET} \text { vS } \\
\text { PBO }+ \text { INS } \pm \text { MET }\end{array}$ & $\begin{array}{l}\text { Barnett et al, } \\
2012[43]\end{array}$ \\
\hline $\mathrm{NCTO0683657}^{\dagger}$ & Phase 3, randomized, 4 wk & 93 & 8.1 & $\begin{array}{l}\text { SAXA } 5 \mathrm{mg} / \mathrm{d}+\text { MET XR vs } \\
\text { PBO + MET XR }\end{array}$ & $\begin{array}{l}\text { Stenlof et al, } \\
2010[44]\end{array}$ \\
\hline${\mathrm{NCT} 00885378^{\dagger}}^{+}$ & Phase 3, randomized, $12 \mathrm{wk}$ & 160 & $7.9-8.0$ & $\begin{array}{l}\text { SAXA ( } 2.5 \mathrm{mg} \text { twice daily) + } \\
\text { MET vs PBO MET }\end{array}$ & $\begin{array}{l}\text { White et al, } \\
2014 \text { [45] }\end{array}$ \\
\hline$\overline{\text { NCT00918138 }}{ }^{\dagger}$ & Phase 3, randomized, 4 wk & 93 & $8.4-8.6$ & $\begin{array}{l}\text { SAXA } 5 \mathrm{mg} / \mathrm{d}+\text { MET XR } \\
1500 \mathrm{mg} \text { VS MET XR } \\
\text { uptitration to } 2000 \mathrm{mg}\end{array}$ & $\begin{array}{l}\text { Neutel et al, } \\
2013[46]\end{array}$ \\
\hline NCT01006590 ${ }^{\dagger}$ & Phase $3 / 4$, randomized, $24 \mathrm{wk}$ & 286 & $7.7-7.8$ & $\begin{array}{l}\text { SAXA } 5 \mathrm{mg} / \mathrm{d}+\text { MET } 1500 \mathrm{mg} \\
\text { vs MET uptitration to } 2000 \\
\text { or } 2500 \mathrm{mg}^{\S}\end{array}$ & $\begin{array}{l}\text { Hermans et al, } \\
2012 \text { [47] }\end{array}$ \\
\hline $\mathrm{NCT00960076}^{\dagger}$ & Phase 3, randomized, $18 \mathrm{wk}$ & 282 & $8.3-8.4$ & $\begin{array}{l}\text { SAXA } 5 \mathrm{mg} / \mathrm{d}+\text { MET XR vs } \\
\text { MET XR uptitration to } \\
1000 \mathrm{mg}^{\S}\end{array}$ & $\begin{array}{c}\text { Fonseca et al, } \\
2012[48]\end{array}$ \\
\hline
\end{tabular}

$\mathrm{GLY}=$ glyburide; $\mathrm{HbA}_{1 \mathrm{c}}=$ glycated hemoglobin; INS = insulin; $\mathrm{LTE}=$ long-term extension; $\mathrm{MET}$ = metformin; $\mathrm{OAD}=$ oral antidiabetic drug; $\mathrm{PBO}=$ placebo; $\mathrm{QAM}=$ once daily in the morning; $\mathrm{QPM}=$ once daily in the evening; $\mathrm{SAXA}=$ saxagliptin; $\mathrm{SITA}=$ sitagliptin; $\mathrm{TZD}=$ thiazolidinedione; $\mathrm{XR}=$ extended release. *Number of randomized and treated patients.

${ }^{\dagger}$ Included in the subset analysis of studies of saxagliptin as add-on therapy to metformin.

${ }^{\ddagger}$ Main cohort only.

${ }^{5}$ Dose increase if hyperglycemia criteria were met, up to maximum indicated dose.

"Dose increased to indicated maximum. 
NCT01006590, NCT00960076). In addition, subgroup analyses of MACE were performed for saxagliptin $2.5 \mathrm{mg}$ versus control and saxagliptin $5 \mathrm{mg}$ versus control in the 20 -study pool. The saxagliptin $2.5-\mathrm{mg}$ group included patients who received an initial dose of saxagliptin $2.5 \mathrm{mg}$ once daily, except for those enrolled in the renal impairment study (NCT00614939). The saxagliptin 5-mg group included patients who received an initial dose of saxagliptin $5 \mathrm{mg}$ once daily or $2.5 \mathrm{mg}$ twice daily. Patients receiving doses of saxagliptin $<2.5 \mathrm{mg} / \mathrm{d}$ or $>5 \mathrm{mg} / \mathrm{d}$ were not included in the analyses by dose.

For MACE and individual CV component events, the number of patients with the event, the time up to an event or censoring (for patients without a MACE), the exposure-adjusted incidence rate (IR), and the incidence rate ratio (IRR), which provides a means to account for differences in study duration and mean follow-up time with saxagliptin and control, were calculated. To account for differences between studies in patients, event rates, and randomization ratios, the IR (number of patients with events per 100 patient-years) with 95\% CI was calculated using the Mantel-Haenszel method, stratified by study. Exact 95\% CI was calculated for the IRR, stratified by study. In addition, adjudicated MACE were analyzed using a Cox proportional hazards model.

\section{Results}

\section{Patient demographics and clinical characteristics}

In the 20-study pool, demographic and clinical characteristics were similar between the saxagliptin $(n=5701)$ and control $(\mathrm{n}=3455)$ groups (Table 2). Most patients were white and $<65$ years of age, and $45 \%$ (control) to $49 \%$ (saxagliptin) had a duration of T2DM of $\leq 3$ years. In the addon to metformin study pool, demographic and clinical characteristics were also similar between the saxagliptin $(\mathrm{n}=2981)$ and control $(\mathrm{n}=2190)$ groups (Table 3$)$. There was a higher proportion of patients with duration of T2DM of $\leq 1.5$ years in the 20-study pool, compared with the 11-study saxagliptin add-on to metformin pool; otherwise, no notable differences were observed between the pooled populations. The total follow-up time for saxagliptin and control for the 20-study pool was 6051 and 2869 patient-years, respectively, with an average follow-up time of 1.06 years/patient and 0.83 years/patient, respectively. The proportion of patients that prematurely discontinued from the study varied based on the length of study. The rate of premature discontinuation was higher with saxagliptin versus control in 3 studies, higher with control versus saxagliptin in 9 studies, and similar between groups in the remaining studies.

\section{Cardiovascular events}

In the 20-study pool, exposure time to the first MACE or censoring was 6039 patient-years in the saxagliptin
Table 2 Patient demographics and clinical characteristics in the 20-study pool

\begin{tabular}{|c|c|c|}
\hline Characteristic, n (\%) & $\begin{array}{l}\text { All SAXA } \\
(n=5701)\end{array}$ & $\begin{array}{l}\text { Control } \\
(n=3455)\end{array}$ \\
\hline \multicolumn{3}{|l|}{ Age, y } \\
\hline$<65$ & $4681(82.1)$ & $2766(80.1)$ \\
\hline$\geq 65$ & $1020(17.9)$ & 689 (19.9) \\
\hline$\geq 75$ & $132(2.3)$ & $91(2.6)$ \\
\hline Women & $2899(50.9)$ & $1696(49.1)$ \\
\hline \multicolumn{3}{|l|}{ Race } \\
\hline White & $3707(65.0)$ & $2034(58.9)$ \\
\hline Asian & $1319(23.1)$ & $1001(29.0)$ \\
\hline Black & $217(3.8)$ & $102(3.0)$ \\
\hline Other & $458(8.0)$ & $318(9.2)$ \\
\hline \multicolumn{3}{|l|}{$\mathrm{BMI}, \mathrm{kg} / \mathrm{m}^{2}$} \\
\hline$<30$ & $2914(51.1)$ & $1888(54.6)$ \\
\hline$\geq 30$ & $2780(48.8)$ & $1564(45.3)$ \\
\hline Not reported & $7(0.1)$ & $3(<0.1)$ \\
\hline \multicolumn{3}{|l|}{ Duration of T2DM, y } \\
\hline$\leq 1.5$ & $2129(37.3)$ & $1076(31.1)$ \\
\hline$\leq 3$ & $2817(49.4)$ & $1558(45.1)$ \\
\hline$>3-<5$ & 776 (13.6) & $523(15.1)$ \\
\hline$\geq 5$ & $2107(37.0)$ & $1373(39.7)$ \\
\hline$\geq 10$ & $834(14.6)$ & $582(16.8)$ \\
\hline Not reported & $1(<0.1)$ & $1(<0.1)$ \\
\hline \multicolumn{3}{|c|}{ Creatinine clearance, $\mathrm{mL} / \mathrm{min}$} \\
\hline$<30$ & $37(0.6)$ & $41(1.2)$ \\
\hline $30-<50$ & $90(1.6)$ & $68(2.0)$ \\
\hline $50-80$ & $973(17.1)$ & $658(19.0)$ \\
\hline$>80$ & $4598(80.7)$ & $2685(77.7)$ \\
\hline Not reported & $3(<0.1)$ & $3(<0.1)$ \\
\hline
\end{tabular}

group versus 2864 patient-years in the control group. A total of 43 patients who received saxagliptin had an adjudicated MACE versus 31 patients in the control group (Figure 1). The IRs per 100 patient-years (SE) were 0.85 (0.14) for saxagliptin and $1.12(0.20)$ for control, with an IRR $(95 \% \mathrm{CI})$ of $0.74(0.45,1.25)$. The Cox proportional hazard ratio (HR; $95 \% \mathrm{CI})$ was $0.75(0.46,1.21)$, suggesting no increased risk of MACE in the 20-study pool.

In the subgroup analyses of adjudicated MACE for saxagliptin 2.5 and $5 \mathrm{mg}$ in the 20-study pool, the IR per 100 patient-years (SE) was $0.47(0.19)$ for saxagliptin $2.5 \mathrm{mg}$ versus $1.38(0.36)$ for control and $0.73(0.15)$ for saxagliptin $5 \mathrm{mg}$ versus 0.97 (0.19) for control. The IRR (95\% CI) for saxagliptin 2.5 and $5 \mathrm{mg}$ were 0.33 (0.10, $0.89)$ and $0.74(0.40,1.36)$, respectively (Figure 1$)$.

In the 11-study pool of saxagliptin add-on to metformin, the exposure time to a first MACE event or censoring was 3287 patient-years in the saxagliptin group versus 1783 
Table 3 Patient demographics and clinical characteristics in the pool of saxagliptin add-on to metformin studies

\begin{tabular}{|c|c|c|}
\hline Characteristic, n (\%) & $\begin{array}{l}\text { All SAXA } \\
(n=2981)\end{array}$ & $\begin{array}{l}\text { Control } \\
(n=2190)\end{array}$ \\
\hline \multicolumn{3}{|l|}{ Age, y } \\
\hline$<65$ & $2397(80.4)$ & $1733(79.1)$ \\
\hline$\geq 65$ & $584(19.6)$ & $457(20.9)$ \\
\hline$\geq 75$ & $86(2.9)$ & $62(2.8)$ \\
\hline Women & $1533(51.4)$ & $1070(48.9)$ \\
\hline \multicolumn{3}{|l|}{ Race } \\
\hline White & $2031(68.1)$ & $1426(65.1)$ \\
\hline Asian & $549(18.4)$ & $469(21.4)$ \\
\hline Black & $109(3.7)$ & $58(2.6)$ \\
\hline Other & $292(9.8)$ & $237(10.8)$ \\
\hline \multicolumn{3}{|l|}{$\mathrm{BMI}, \mathrm{kg} / \mathrm{m}^{2}$} \\
\hline$<30$ & $1438(48.2)$ & $1114(50.9)$ \\
\hline$\geq 30$ & $1541(51.7)$ & $1074(49.0)$ \\
\hline Not reported & $2(<0.1)$ & $2(<0.1)$ \\
\hline \multicolumn{3}{|l|}{ Duration of T2DM, y } \\
\hline$\leq 1.5$ & $828(27.8)$ & $504(23.0)$ \\
\hline$\leq 3$ & $1198(40.2)$ & $833(38.0)$ \\
\hline$>3-<5$ & $475(15.9)$ & $386(17.6)$ \\
\hline$\geq 5$ & $1308(43.9)$ & $971(44.3)$ \\
\hline$\geq 10$ & $489(16.4)$ & $391(17.9)$ \\
\hline \multicolumn{3}{|c|}{ Creatinine clearance, $\mathrm{mL} / \mathrm{min}$} \\
\hline $30-<50$ & $28(0.9)$ & $14(0.6)$ \\
\hline $50-80$ & $493(16.5)$ & $405(18.5)$ \\
\hline$>80$ & $2457(82.4)$ & $1768(80.7)$ \\
\hline Not reported & $3(0.1)$ & $3(0.1)$ \\
\hline
\end{tabular}

patient-years in the control group. A total of 23 patients who received saxagliptin had an adjudicated MACE versus 14 patients in the control group (Figure 1). The IR per 100 patient-years (SE) was similar for saxagliptin $(0.79$ [0.17]) and control $(0.85[0.23])$, yielding an IRR $(95 \% \mathrm{CI})$ of 0.93 $(0.44,1.99)$.

In the 20-study pool, the IR point estimates (SE) for the individual components of MACE were 0.34 (0.09) for saxagliptin versus $0.54(0.14)$ for control for $\mathrm{CV}$ death; $0.40(0.10)$ versus $0.45(0.13)$, respectively, for MI; and $0.27(0.07)$ versus $0.36(0.11)$ for stroke (Figure 2). In the 11-study pool of saxagliptin add-on to metformin, IR estimates (SE) for saxagliptin versus control were $0.27(0.10)$ versus $0.49(0.18)$ for $\mathrm{CV}$ death, 0.44 (0.13) versus $0.31(0.14)$ for $\mathrm{MI}$, and $0.21(0.08)$ versus 0.22 (0.11) for stroke. IRRs for these events ranged from 0.51 to 1.49 (Figure 3).

Heart failure was not defined as a component of MACE and was not adjudicated but was analyzed separately. For heart failure (20-study pool only), the IR (SE) was 0.34 $(0.08)$ and $0.62(0.15)$ for saxagliptin and control, respectively. IRRs for these individual events ranged between 0.55 and 0.87 (Figure 2).

\section{Discussion}

In this pooled analysis of 9156 patients with T2DM from 20 phase 2 and 3 clinical trials, treatment with saxagliptin was not associated with an increased risk of $\mathrm{CV}$ events and heart failure compared with placebo or active comparator. These results expand on previous findings on the CV safety of saxagliptin reported in a metaanalysis of 8 phase 2 and 3 trials [27]. In that analysis, a total of 40 MACE events in 4607 patients were reported. The relative risk $(95 \% \mathrm{CI})$ for saxagliptin versus comparator for a composite endpoint of adjudicated $\mathrm{CV}$ death, MI, and stroke was $0.43(0.23,0.80)$, which suggested possible $\mathrm{CV}$ protection with saxagliptin. The

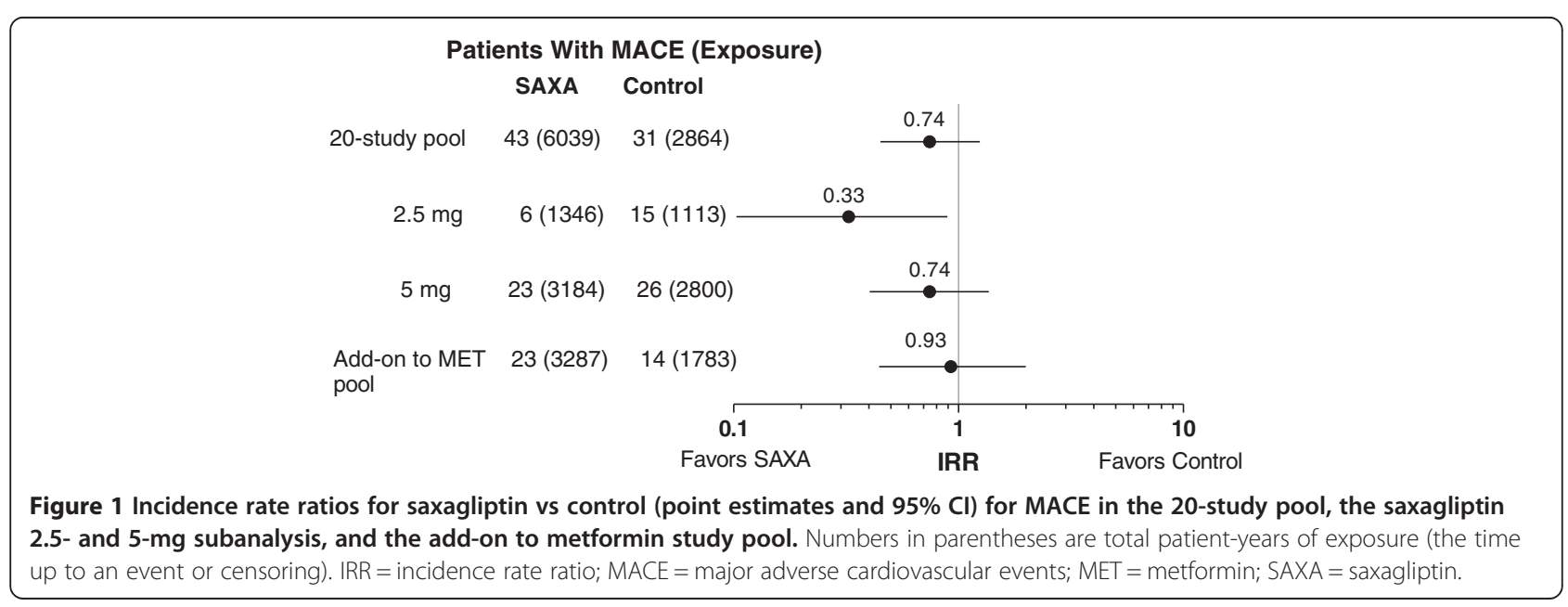




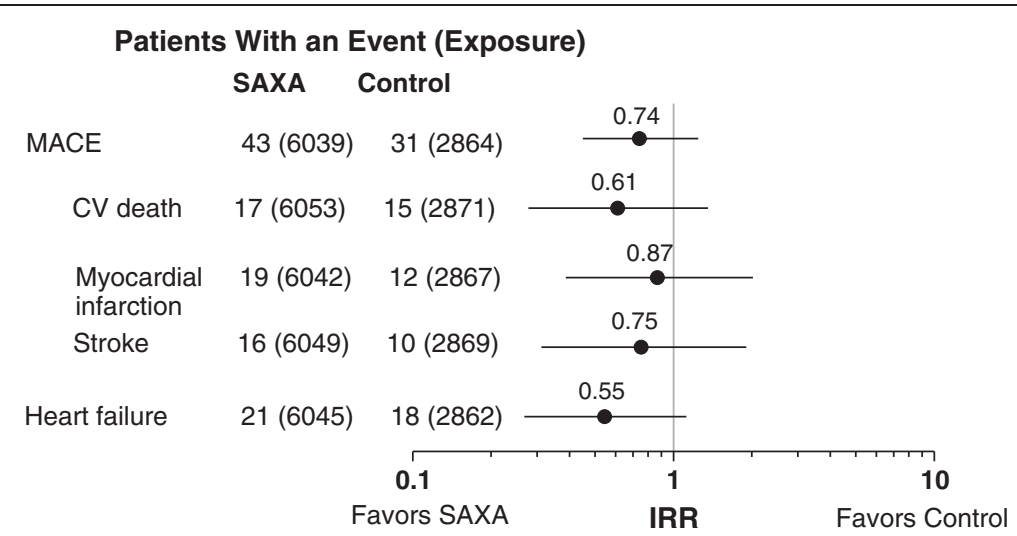

Figure 2 Incidence rate ratios for saxagliptin vs control (point estimates and $95 \% \mathrm{Cl}$ ) for $\mathrm{CV}$ death, myocardial infarction, stroke, and heart failure in the 20-study pool. Numbers in parentheses are total patient-years of exposure (the time up to an event or censoring). $\mathrm{CV}=$ cardiovascular; IRR = incidence rate ratio; $\mathrm{MACE}=$ major adverse cardiovascular events; SAXA = saxagliptin.

present analysis expanded on the previous study and included 9156 patients who experienced 74 MACE events. In this larger population, which should provide a more precise risk estimate, the relative risk $(95 \% \mathrm{CI})$ for a composite endpoint of adjudicated $\mathrm{CV}$ death, MI, and stroke was $0.75(0.46,1.21)$, suggesting no increased risk of MACE in this 20-study pool. Incidence rates for $\mathrm{CV}$ events for saxagliptin were not different from those for placebo or comparator in most analyses, with the exception of the lower IR for MACE in the saxagliptin 2.5-mg group in the subanalysis of the 20-study pool. However, it should be noted that only 7 of the 20 studies included patients who had received the 2.5 -mg saxagliptin dose.

The present findings are also consistent with previously published meta-analyses of $\mathrm{CV}$ events from clinical trial programs for other DPP-4 inhibitors, including vildagliptin, sitagliptin, linagliptin, and alogliptin. In a pooled analysis of 25 clinical trials, the relative risk (95\% CI) for cardiocerebrovascular events for vildagliptin was
$0.88(0.37,2.11)$ for $50 \mathrm{mg}$ once daily and $0.84(0.62$, 1.14) for $50 \mathrm{mg}$ twice daily [49]. In other meta-analyses, the IRR or HR (95\% CI) for CV-related events versus comparators was $0.83(0.53-1.30)$ for sitagliptin [50], $0.34(0.16,0.70)$ for linagliptin [51], and 0.64 (1-sided 97.5\% CI, 0.0, 1.406) for alogliptin [52]. In addition, a meta-analysis of 70 trials of DPP-4 inhibitors enrolling 41,959 patients reported a reduction in MACE $(n=495$ total events of $\mathrm{CV}$ death, nonfatal MI, and stroke and acute coronary syndromes and/or heart failure; odds ratio, 0.71 [95\% CI, 0.59, 0.86]) [53]. Although these studies are not directly comparable because of different $\mathrm{CV}$ endpoints, study designs, adjudication procedures, patient populations and background medication, all supported the hypothesis that DPP-4 inhibitors do not increase $\mathrm{CV}$ risk and may possibly have $\mathrm{CV}$ benefits in patients with T2DM.

Results from the large outcome trial of saxagliptin in patients with prior $\mathrm{CV}$ disease or multiple $\mathrm{CV}$ risk factors

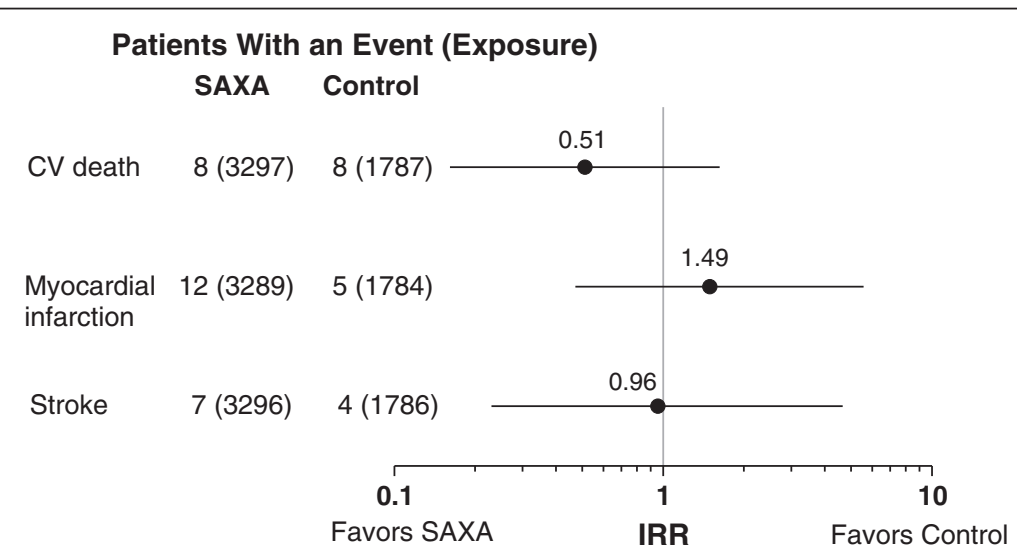

Figure 3 Incidence rate ratios for saxagliptin vs control (point estimates and 95\% Cl) for CV death, myocardial infarction, and stroke in the add-on to metformin study pool. Numbers in parentheses are total patient-years of exposure (the time up to an event or censoring). $\mathrm{CV}=$ cardiovascular; IRR = incidence rate ratio; SAXA = saxagliptin. 
(SAVOR) have recently been reported [25]. Results generally consistent with those were also reported from the alogliptin trial (EXAMINE) in patients after acute coronary syndrome [26]. SAVOR demonstrated neutrality on the composite primary endpoint of $\mathrm{CV}$ death, $\mathrm{MI}$, or ischemic stroke (HR, 1.00 [95\% CI, 0.89, 1.12]). The MACE results reported here in a much lower-risk population with an event rate approximately a third of that observed in SAVOR are consistent with SAVOR in demonstrating a safe profile of saxagliptin with respect to MACE events. The fact that SAVOR did not demonstrate superiority compared with placebo raises at least two alternative, though not mutually exclusive, interpretations: (1) evidence suggesting benefit from metaanalysis and preclinical evidence [16,54] was due to chance or (2) saxagliptin and likely other DPP-4 inhibitors are safe in all populations and trends to benefit occur only in the lower-risk general population studied in the phase 3 clinical development program. The latter hypothesis has been previously suggested based on the only positive interaction of subgroups in a patient level meta-analysis of UKPDS, ACCORD, ADVANCE, and VADT [55]. Owing to the marked difference in population characteristics (eg, age, CV history and risk factors, duration of diabetes, background diabetes and CV medications, proportion of patients with baseline glycated hemoglobin $<7 \%$ ) and population risk (3- to 6-fold higher event rate) between SAVOR and EXAMINE and the meta-analyses of phase 3 programs of saxagliptin and alogliptin, it is difficult to support or dismiss either interpretation for the lack of benefit observed in SAVOR and EXAMINE.

SAVOR also demonstrated neutrality on the broader composite endpoint of CV death, MI, stroke, or hospitalization for unstable angina, heart failure, or coronary revascularization ( $\mathrm{HR}, 1.02$ [95\% CI, 0.94, 1.11]). One component of this broader endpoint, hospitalization for heart failure, did have an HR with 95\% CI which did not include 1 (HR, 1.27 [95\% CI, 1.07, 1.51]). As reported here, heart failure in the 20-study pool had an HR (95\% CI) of $0.55(0.27,1.12)$. Again, differences in the patient population, background medications, and/or chance may be involved in the relative inconsistency of these results. Moreover, SAVOR was an event-driven trial in a highly defined population (prior $\mathrm{CV}$ disease or multiple $\mathrm{CV}$ risk factors), whereas the 20 clinical trials analyzed in this study had defined treatment periods ranging from 4 to 206 weeks and included diverse patient populations with T2DM (eg, patients who were treatment naïve, receiving varying background antihyperglycemic medications, or with renal impairment). The phase 3 data presented in this manuscript suggest that the observation of hospitalization for heart failure could not have been anticipated based on the phase 3 development program. It may be that further analysis of SAVOR results or the other prospective CV outcome trials with DPP-4 inhibitors $[56,57]$ will give further clarity to the two issues raised here.

Certain limitations of this analysis should be recognized and considered when interpreting the results. To handle missing data as the result of premature discontinuation, analysis methods assumed similar event rates had the patient completed the study. However, patients treated with saxagliptin tended to be followed longer and had a lower rate of discontinuation compared with those who received control treatment. Results using this assumption should be interpreted with caution.

Both groups received a range of background medications, including metformin, sulfonylureas, and thiazolidinediones and the control group received both active medications and placebo. In several studies, a titration of background medication [22,41,46-48] or a titration of double-blind saxagliptin $[19,29,30,39,40]$ was permitted. In addition, in the majority of studies, rescue medication was permitted [19-23,32,36,38-43]. These factors complicate interpretation of the findings.

The saxagliptin group was also heterogeneous and included patients treated with doses higher than the approved 2.5- and 5-mg once-daily doses. Further, the analyses of the 2.5- and the 5-mg doses used distinct study pools because not all studies included 2.5- and 5-mg arms, which precludes direct comparison of results for the 2 doses. It is important to recognize that the pooled patient population in these clinical trials was highly selected, which may have resulted in a lower event rate compared with that observed in clinical practice. Finally, there was relatively limited experience beyond 18 months.

\section{Conclusion}

Pooled data from 20 clinical trials involving 9156 patients with T2DM suggest that saxagliptin is safe and not associated with an increased $\mathrm{CV}$ risk.

\section{Abbreviations}

AEs: Adverse events; BMl: Body mass index; Cl: Confidence intervals; CV: Cardiovascular; DCRI: Duke Clinical Research Institute; DPP-4: Dipeptidyl peptidase-4; GLP-1: Glucagon-like peptide-1; GLY: Glyburide; HbA 1c: Glycated hemoglobin; INS: Insulin; IR: Incidence rate; IRR: Incidence rate ratio; LTE: Long-term extension; MACE: Major adverse cardiovascular events; MedDRA: Medical Dictionary for Regulatory Activities; MET: Metformin; MHI: Montreal Heart Institute; MI: Myocardial infarction; OAD: Oral antidiabetic drug; PBO: Placebo; QAM: Once daily in the morning QPM: Once daily in the evening; SAEs: Serious adverse events; SAXA: Saxagliptin; SITA: Sitagliptin; SMQ: Standardized MedDRA Queries; T2DM: Type 2 diabetes mellitus; TZD: Thiazolidinedione; XR: Extended release.

\section{Competing interests}

$\mathrm{NI}, \mathrm{RF}$, and MD are employees of Bristol-Myers Squibb. AP and BH are employees of AstraZeneca.

\section{Authors' contributions}

$\mathrm{NI}$ contributed to the conception and design of the study and the drafting and final approval of the manuscript. AP contributed to the conception and design of the study and the drafting, revision, and final approval of the 
manuscript. RF contributed to the conception and design of the study and the drafting, revision, and final approval of the manuscript. MD contributed to the conception and design of the study, analyzed the data, and revised and approved the final version of the manuscript. $\mathrm{BH}$ contributed to the conception and design of the study and the drafting, revision, and final approval of the manuscript.

\section{Acknowledgements}

Bristol-Myers Squibb and AstraZeneca funded this study. Medical writing support for the preparation of this manuscript was provided by Richard M. Edwards, PhD, and Janet E. Matsuura, PhD, from Complete Healthcare Communications, Inc., with funding from Bristol-Myers Squibb and AstraZeneca.

\section{Author details}

${ }^{1}$ Bristol-Myers Squibb, Route 206 \& Providence Line Rd, Princeton, NJ 08543 USA. ${ }^{2}$ AstraZeneca, 1800 Concord Pike, Wilmington, DE 19850, USA.

Received: 25 November 2013 Accepted: 26 January 2014 Published: 4 February 2014

\section{References}

1. National diabetes fact sheet: national estimates and general information on diabetes and prediabetes in the United States. [http://www.cdc.gov/ diabetes/pubs/pdf/ndfs_2011.pdf]

2. Go AS, Mozaffarian D, Roger VL, Benjamin EJ, Berry JD, Borden WB, Bravata DM, Dai S, Ford ES, Fox CS, et al: Heart disease and stroke statistics-2013 update: a report from the American Heart Association. Circulation 2013, 127(1):e6-e245.

3. Cavalot F, Pagliarino A, Valle M, Di Martino L, Bonomo K, Massucco P, Anfossi G, Trovati M: Postprandial blood glucose predicts cardiovascular events and all-cause mortality in type 2 diabetes in a 14-year follow-up: lessons from the San Luigi Gonzaga Diabetes Study. Diabetes Care 2011, 34(10):2237-2243

4. DECODE Study Group, European Diabetes Epidemiology Group: Is the current definition for diabetes relevant to mortality risk from all causes and cardiovascular and noncardiovascular diseases? Diabetes Care 2003, 26(3):688-696.

5. Selvin E, Marinopoulos S, Berkenblit G, Rami T, Brancati FL, Powe NR, Golden SH: Meta-analysis: glycosylated hemoglobin and cardiovascular disease in diabetes mellitus. Ann Intern Med 2004, 141(6):421-431.

6. Duckworth W, Abraira C, Moritz T, Reda D, Emanuele N, Reaven PD, Zieve FJ, Marks J, Davis SN, Hayward R, et al: Glucose control and vascular complications in veterans with type 2 diabetes. N Engl J Med 2009, 360(2):129-139.

7. Gerstein HC, Miller ME, Byington RP, Goff DC Jr, Bigger JT, Buse JB, Cushman WC, Genuth S, Ismail-Beigi F, Grimm RH Jr, et al: Effects of intensive glucose lowering in type 2 diabetes. N Engl J Med 2008, 358(24):2545-2559.

8. Patel A, MacMahon S, Chalmers J, Neal B, Billot L, Woodward M, Marre M, Cooper M, Glasziou P, Grobbee D, et al: Intensive blood glucose control and vascular outcomes in patients with type 2 diabetes. $N$ Engl J Med 2008, 358(24):2560-2572.

9. Meinert $\mathrm{CL}$, Knatterud GL, Prout TE, Klimt CR: A study of the effects of hypoglycemic agents on vascular complications in patients with adultonset diabetes II. Mortality results. Diabetes 1970, 19(suppl):789-830.

10. Nissen SE, Wolski K: Effect of rosiglitazone on the risk of myocardial infarction and death from cardiovascular causes. N Engl J Med 2007, 356(24):2457-2471.

11. Nathan DM, Cleary PA, Backlund JY, Genuth SM, Lachin JM, Orchard TJ, Raskin P, Zinman B: Intensive diabetes treatment and cardiovascular disease in patients with type 1 diabetes. N Engl J Med 2005, 353(25):2643-2653.

12. Holman RR, Paul SK, Bethel MA, Matthews DR, Neil HA: 10-year follow-up of intensive glucose control in type 2 diabetes. N Engl J Med 2008, 359 (15):1577-1589.

13. Guidance for industry: diabetes mellitus - evaluating cardiovascular risk in new antidiabetic therapies to treat type 2 diabetes. [http://www.fda.gov/ downloads/Drugs/GuidanceComplianceRegulatoryInformation/Guidances/ ucm071627.pdf

14. Onglyza ${ }^{\oplus}$ : saxagliptin. Princeton, NJ: Bristol-Myers Squibb Company; 2013.
15. Drucker DJ, Nauck MA: The incretin system: glucagon-like peptide-1 receptor agonists and dipeptidyl peptidase-4 inhibitors in type 2 diabetes. Lancet 2006, 368(9548):1696-1705

16. Scheen AJ: Cardiovascular effects of gliptins. Nat Rev Cardiol 2013, 10(2):73-84

17. Lee SA, Kim YR, Yang EJ, Kwon EJ, Kim SH, Kang SH, Park DB, Oh BC, Kim J, Heo ST, et al: CD26/DPP4 levels in peripheral blood and T cells in patients with type 2 diabetes mellitus. J Clin Endocrinol Metab 2013, 98(6):2553-2561.

18. Ravassa S, Barba J, Coma-Canella I, Huerta A, Lopez B, Gonzalez A, Diez J: The activity of circulating dipeptidyl peptidase-4 is associated with subclinical left ventricular dysfunction in patients with type 2 diabetes mellitus. Cardiovasc Diabetol 2013, 12:143.

19. Frederich $R$, McNeill R, Berglind N, Fleming D, Chen R: The efficacy and safety of the dipeptidyl peptidase-4 inhibitor saxagliptin in treatmentnaive patients with type 2 diabetes mellitus: a randomized controlled trial. Diabetol Metab Syndr 2012, 4(1):36.

20. Rosenstock J, Aguilar-Salinas C, Klein E, Nepal S, List J, Chen R: Effect of saxagliptin monotherapy in treatment-naive patients with type 2 diabetes. Curr Med Res Opin 2009, 25(10):2401-2411.

21. DeFronzo RA, Hissa MN, Garber AJ, Luiz Gross J, Yuyan Duan R, Ravichandran S, Chen RS: The efficacy and safety of saxagliptin when added to metformin therapy in patients with inadequately controlled type 2 diabetes with metformin alone. Diabetes Care 2009, 32(9):1649-1655.

22. Chacra AR, Tan GH, Apanovitch A, Ravichandran S, List J, Chen R: Saxagliptin added to a submaximal dose of sulphonylurea improves glycaemic control compared with uptitration of sulphonylurea in patients with type 2 diabetes: a randomised controlled trial. Int J Clin Pract 2009, 63(9):1395-1406.

23. Hollander P, Li J, Allen E, Chen R, for the CV181-013 Investigators: Saxagliptin added to a thiazolidinedione improves glycemic control in patients with type 2 diabetes and inadequate control on thiazolidinedione alone. J Clin Endocrinol Metab 2009, 94(12):4810-4819.

24. Inzucchi SE, Bergenstal RM, Buse JB, Diamant M, Ferrannini E, Nauck M Peters AL, Tsapas A, Wender R, Matthews DR: Management of hyperglycemia in type 2 diabetes: a patient-centered approach: position statement of the American Diabetes Association (ADA) and the European Association for the Study of Diabetes (EASD). Diabetes Care 2012, 35(6):1364-1379.

25. Scirica BM, Bhatt DL, Braunwald E, Steg PG, Davidson J, Hirshberg B, Ohman $P$, Frederich $R$, Wiviott SD, Hoffman EB, et al: Saxagliptin and cardiovascular outcomes in patients with type 2 diabetes mellitus. $N$ Engl $J$ Med 2013, 369(14):1317-1326.

26. White WB, Cannon CP, Heller SR, Nissen SE, Bergenstal RM, Bakris GL, Perez $A T$, Fleck PR, Mehta CR, Kupfer $S$, et al: Alogliptin after acute coronary syndrome in patients with type 2 diabetes. N Engl J Med 2013, 369(14):1327-1335

27. Frederich $\mathrm{R}$, Alexander JH, Fiedorek FT, Donovan M, Berglind N, Harris S, Chen R, Wolf R, Mahaffey KW: A systematic assessment of cardiovascular outcomes in the saxagliptin drug development program for type 2 diabetes. Postgrad Med 2010, 122(3):16-27.

28. Rosenstock J, Sankoh S, List JF: Glucose-lowering activity of the dipeptidyl peptidase-4 inhibitor saxagliptin in drug-naive patients with type 2 diabetes. Diabetes Obes Metab 2008, 10(5):376-386.

29. Göke B, Gallwitz B, Eriksson J, Hellqvist A, Gause-Nilsson I: Saxagliptin is non-inferior to glipizide in patients with type 2 diabetes mellitus inadequately controlled on metformin alone: a 52-week randomised controlled trial. Int J Clin Pract 2010, 64(12):1619-1631.

30. Göke B, Gallwitz B, Eriksson JG, Hellqvist A, Gause-Nilsson I: Saxagliptin vs. glipizide as add-on therapy in patients with type 2 diabetes mellitus inadequately controlled on metformin alone: long-term (52-week) extension of a 52-week randomised controlled trial. Int J Clin Pract 2013, 67(4):307-316.

31. Scheen AJ, Charpentier G, Ostgren CJ, Hellqvist A, Gause-Nilsson I: Efficacy and safety of saxagliptin in combination with metformin compared with sitagliptin in combination with metformin in adult patients with type 2 diabetes mellitus. Diabetes Metab Res Rev 2010, 26(7):540-549.

32. Pan CY, Yang W, Tou C, Gause-Nilsson I, Zhao J: Efficacy and safety of saxagliptin in drug-naive Asian patients with type 2 diabetes mellitus: a randomized controlled trial. Diabetes Metab Res Rev 2012, 28(3):268-275. 
33. Yang W, Pan CY, Tou C, Zhao J, Gause-Nilsson I: Efficacy and safety of saxagliptin added to metformin in Asian people with type 2 diabetes mellitus: a randomized controlled trial. Diabetes Res Clin Pract 2011, 94(2):217-224

34. Nowicki M, Rychlik I, Haller H, Warren L, Suchower L, Gause-Nilsson I: Saxagliptin improves glycaemic control and is well tolerated in patients with type 2 diabetes mellitus and renal impairment. Diabetes Obes Metab 2011, 13(6):523-532

35. Nowicki M, Rychlik I, Haller H, Warren M, Suchower L, Gause-Nilsson I, Schutzer KM: Long-term treatment with the dipeptidyl peptidase-4 inhibitor saxagliptin in patients with type 2 diabetes mellitus and renal impairment: a randomised controlled 52-week efficacy and safety study. Int J Clin Pract 2011, 65(12):1230-1239.

36. Prasanna Kumar KM, Jain SM, Tou C, Schutzer KM: Saxagliptin as initial therapy in treatment-naive Indian adults with type 2 diabetes mellitus inadequately controlled with diet and exercise alone: A randomized, double-blind, placebo-controlled, phase IIlb clinical study. Int I Diabetes Devel Countries 2014: [Epub ahead of print].

37. Rosenstock J, Gross JL, Aguilar-Salinas C, Hissa M, Berglind N, Ravichandran S, Fleming D: Long-term 4-year safety of saxagliptin in drug-naive and metformin-treated patients with Type 2 diabetes. Diabet Med 2013, 30(12):1472-1476.

38. Hollander PL, Li J, Frederich R, Allen E, Chen R, and the CV181013 Investigators: Safety and efficacy of saxagliptin added to thiazolidinedione over 76 weeks in patients with type 2 diabetes mellitus. Diab Vasc Dis Res 2011, 8(2):125-135.

39. Jadzinsky M, Pfutzner A, Paz-Pacheco E, Xu Z, Allen E, Chen R: Saxagliptin given in combination with metformin as initial therapy improves glycaemic control in patients with type 2 diabetes compared with either monotherapy: a randomized controlled trial. Diabetes Obes Metab 2009, 11(6):611-622

40. Pfützner A, Paz-Pacheco E, Allen E, Frederich B, Chen R, for the CV181039 Investigators: Initial combination therapy with saxagliptin and metformin provides sustained glycaemic control and is well tolerated for up to 76 weeks. Diabetes Obes Metab 2011, 13(6):567-576.

41. Chacra AR, Tan GH, Ravichandran S, List J, Chen R, and the CV181040 Investigators: Safety and efficacy of saxagliptin in combination with submaximal sulphonylurea versus up-titrated sulphonylurea over 76 weeks. Diab Vasc Dis Res 2011, 8(2):150-159.

42. Henry RR, Smith SR, Schwartz SL, Mudaliar SR, Deacon CF, Holst JJ, Duan RY, Chen RS, List JF: Effects of saxagliptin on beta-cell stimulation and insulin secretion in patients with type 2 diabetes. Diabetes Obes Metab 2011, 13(9):850-858

43. Barnett AH, Charbonnel B, Donovan M, Fleming D: Effect of saxagliptin as add-on therapy in patients with poorly controlled type 2 diabetes on insulin alone or insulin combined with metformin. Curr Med Res Opin 2012, 28(4):513-523.

44. Stenlof K, Raz I, Neutel J, Ravichandran S, Berglind N, Chen R: Saxagliptin and metformin XR combination therapy provides glycemic control over 24 hours in patients with T2DM inadequately controlled with metformin. Curr Med Res Opin 2010, 26(10):2355-2363.

45. White $J$, Buchanan $\mathrm{P}, \mathrm{Li} \mathrm{J}$, Frederich R: A randomized controlled trial of the efficacy and safety of twice-daily saxagliptin plus metformin combination therapy in patients with type 2 diabetes and inadequate glycemic control on metformin monotherapy. BMC Emdocrine Disorders. In press.

46. Neutel JM, Zhao C, Karyekar CS: Adding saxagliptin to metformin extended release (XR) or uptitration of metformin XR: efficacy on daily glucose measures. Diabetes Ther 2013, 4(2):269-283.

47. Hermans MP, Delibasi T, Farmer I, Lohm L, Maheux P, Piatti P, Malvolti E, Jorgens S, Charbonnel B: Effects of saxagliptin added to sub-maximal doses of metformin compared with uptitration of metformin in type 2 diabetes: the PROMPT study. Curr Med Res Opin 2012, 28(10):1635-1645.

48. Fonseca V, Zhu T, Karyekar C, Hirshberg B: Adding saxagliptin to extendedrelease metformin vs. uptitrating metformin dosage. Diabetes Obes Metab 2012, 14(4):365-371.

49. Schweizer A, Dejager S, Foley JE, Couturier A, Ligueros-Saylan M, Kothny W: Assessing the cardio-cerebrovascular safety of vildagliptin: meta-analysis of adjudicated events from a large phase III type 2 diabetes population. Diabetes Obes Metab 2010, 12:485-494.
50. Engel SS, Golm GT, Shapiro D, Davies MJ, Kaufman KD, Goldstein BJ: Cardiovascular safety of sitagliptin in patients with type 2 diabetes mellitus: a pooled analysis. Cardiovasc Diabetol 2013, 12:3.

51. Johansen OE, Neubacher D, von Eynatten M, Patel S, Woerle HJ: Cardiovascular safety with linagliptin in patients with type 2 diabetes mellitus: a pre-specified, prospective, and adjudicated meta-analysis of a phase 3 programme. Cardiovasc Diabetol 2012, 11:3.

52. White WB, Pratley $R$, Fleck $P$, Munsaka M, Hisada M, Wilson C, Menon V: Cardiovascular safety of the dipetidyl peptidase-4 inhibitor alogliptin in type 2 diabetes mellitus. Diabetes Obes Metab 2013, 15(7):668-673.

53. Monami M, Ahren B, Dicembrini I, Mannucci E: Dipeptidyl peptidase-4 inhibitors and cardiovascular risk: a meta-analysis of randomized clinical trials. Diabetes Obes Metab 2013, 15(2):112-120.

54. Dai Y, Dai D, Mercanti F, Ding Z, Wang X, Mehta JL: Dipeptidyl peptidase-4 inhibitors in cardioprotection: a promising therapeutic approach. Acta Diabetol 2013, 50(6):827-835.

55. Turnbull FM, Abraira C, Anderson RJ, Byington RP, Chalmers JP, Duckworth WC, Evans GW, Gerstein HC, Holman RR, Moritz TE, et al: Intensive glucose control and macrovascular outcomes in type 2 diabetes. Diabetologia 2009, 52(11):2288-2298.

56. CAROLINA: cardiovascular outcome study of linagliptin versus glimepiride in patients with type 2 diabetes. [http://clinicaltrials.gov/ct2/ show/NCT01243424?term=nct01243424\&rank=1]

57. TECOS: A randomized, placebo controlled clinical Trial to Evaluate Cardiovascular Outcomes after treatment with Sitagliptin in patients with type 2 diabetes mellitus and inadequate glycemic control. [http://clinicaltrials.gov/ct2/show/NCT00790205?term=NCT00790205\&rank=1]

doi:10.1186/1475-2840-13-33

Cite this article as: labal et al:: Assessment of the cardiovascular safety of saxagliptin in patients with type 2 diabetes mellitus: pooled analysis of 20 clinical trials. Cardiovascular Diabetology 2014 13:33.

\section{Submit your next manuscript to BioMed Central and take full advantage of:}

- Convenient online submission

- Thorough peer review

- No space constraints or color figure charges

- Immediate publication on acceptance

- Inclusion in PubMed, CAS, Scopus and Google Scholar

- Research which is freely available for redistribution 